\title{
Utilizing microsatellite instability and immunohistochemistry to clinically interpret a novel germline mismatch repair mutation of uncertain significance
}

\author{
Whitney L Ducaine*, Lindsay Dohany, Richard Zekman, Dana Zakalik \\ From 14th Annual Meeting of the Collaborative Group of the Americas on Inherited Colorectal Cancer \\ Dallas, TX, USA. 12-13 October 2010
}

\section{Background}

Lynch syndrome (LS) is responsible for around $2-3 \%$ of all colorectal cancers [1]. Germline mutations within one of four mismatch repair (MMR) genes, $M L H 1$, $M S H 2$, MSH6, or PMS2, cause an increased risk in colorectal, endometrial, urinary tract, and other cancers. Tumor screening, by microsatellite instability (MSI) and immunohistochemistry (IHC) analysis, can be utilized prior to mutation analysis in order to streamline the testing process [2]. The following describes the use of MSI and IHC to aid in the clinical interpretation of a novel MMR mutation of uncertain significance and the direct impact on cancer detection.

\section{Materials and methods/results}

Family X presented to our cancer genetics clinic with a previously identified $M S H 2$ MMR gene variant of uncertain significance, 1227del12, detected in Sib 1, who was diagnosed with synchronous colon cancers at age 53. This mutation is an in-frame deletion of four amino acids (Gln, Gly, Ile, Asn) in exon 7, which is located in an alpha-helix turn of the protein. Sib 2 had a bladder cancer at 56 years, and Sib 3 had a ureter cancer at 62 years. Sibs 2 and 3 were tested by standard DNA sequencing for the specific VUS [6]. All three Sibs carry the MSH2 1227del12 mutation. This mutation has not been previously reported in the literature; hence clinical interpretation of this VUS was limited. For this reason, coordination of MSI and IHC was pursued for the three

\footnotetext{
* Correspondence: Whitney.ducaine@beaumonthospitals.com Cancer Genetics Program, William Beaumont Hospital, Royal Oak, Michigan, USA
}

Sibs' tumors. MSI was high for Sibs 2 and 3 and unable to be performed on Sib 1. All three Sibs' tumors showed concurrent loss of MSH2 and MSH6 by IHC.

\section{Conclusions}

This IHC pattern is suspicious of an underlying germline mutation within the $M S H 2$ gene [4,5]. In addition, both of the tested tumors were MSI-high. Given these results, and a significant family history, Family $\mathrm{X}$ was clinically diagnosed with LS, with the MSH2 VUS as the likely cause. Relatives with the VUS were informed to follow LS management recommendations, and those without the VUS should undergo high risk screening $[2,3]$. Sib 2 then underwent a colonoscopy one year from a previous unremarkable colonoscopy, and a Stage I, $1.2 \mathrm{~cm}$ proximal colon adenocarcinoma with focal mucin production was detected.

This case illustrates the benefit of tumor screening and genetic professional expertise in the clinical interpretation of a MMR VUS as it applies to clinical diagnosis, early detection and management of high risk families.

Published: 10 March 2011

\section{References}

1. Lynch HT, et al: Review of the Lynch syndrome: history, molecular genetics, screening, differential diagnosis, and medicolegal ramifications. Clin Genet 2009, 76:1-18.

2. Lindor NM, et al: Recommendations for the care of individuals with an inherited predisposition to Lynch syndrome: a systematic review. JAMA 2006, 296(12):1507-1517.

3. National Comprehensive Cancer Network (NCCN) Guidelines: 2010 [http://www.ncen.org].

4. Hampel $\mathrm{H}$, et al: Screening for Lynch syndrome (hereditary nonpolyposis colorectal cancer). N Engl J Med 2005, 352(18):1851-60. 
5. Shia J, et al: Immunohistochemistry as first-line screening for detecting colorectal cancer patients at risk for hereditary nonpolyposis colorectal cancer syndrome: a 2-antibody panel may be as predictive as a 4-antibody panel. Am J Surg Pathol 2009, 33(11):1639-1645.

6. Colaris $^{\circledR}$ Technical Specifications, Myriad Genetic Laboratories: 2009 [http://www.myriad.com].

doi:10.1186/1897-4287-9-S1-P9

Cite this article as: Ducaine et al: Utilizing microsatellite instability and immunohistochemistry to clinically interpret a novel germline mismatch repair mutation of uncertain significance. Hereditary Cancer in Clinical Practice 2011 9(Suppl 1):P9.

Submit your next manuscript to BioMed Central and take full advantage of:

- Convenient online submission

- Thorough peer review

- No space constraints or color figure charges

- Immediate publication on acceptance

- Inclusion in PubMed, CAS, Scopus and Google Scholar

- Research which is freely available for redistribution

Submit your manuscript at www.biomedcentral.com/submit
C Biomed Central 